\title{
Phosphofructokinase in Human Fetus
}

\author{
AXEL KAHN, ${ }^{(15)}$ DOMINIQUE COTTREAU, AND JEAN CLAUDE DREYFUS \\ Inserum U 129. Institut de Pathologie Moléculaire, CHU Cochin, 24 rue du Faubourg St Jacques, 75674 Paris Cedex \\ 14, France
}

\section{Summary}

The isozymic composition of phosphofructokinase (EC. 2.7.1.11) from human fetal tissues has been investigated by immunological characterization, electrophoresis, purification, and SDS-polyacrylamide gel electrophoresis of the dissociated subunits.

One of the characteristics of fetal tissues is the indiscriminate expression by all the cells of two or three of the basic forms of phosphofructokinase without any isozyme really corresponding to a specifically fetal form. In particular, L-type enzyme, identical to the highly regulatory enzyme synthesized by the adult hepatocytes, is found in most fetal tissues, especially in muscle and brain. $M$ type subunits are also detected in most of the organs and constitute the major form in fetal muscle and adrenals. F-type subunits are predominant in fetal stomach and yolk sack and are practically the only form in fetal heart.

Some electrophoretic and chromatographic differences between fetal and adult M-type phosphofructokinase exist; whether their nature is genetic or posttraductional is so far unknown.

Some differences (of molecular weight and chromatographic properties) are also detected between the fetal L-type subunits and enzyme from adult granulocytes. A mild proteolytic attack of the former by subtilisin transforms it into an enzyme form indistinguishable from granulocyte phosphofructokinase.

\section{Speculation}

In the fetus as well as in adult tissue, phosphofructokinase could be coded by a three-gene-system, coding for the $M, L$, and $F$ subunits. The $M$ and $L$ subunits could undergo some postsynthetic changes, increasing the heterogeneity of phosphofructokinase in the various tissues.

One of the characteristics of the "fetal state" could be the indiscriminate expression of several of the basic genes; differenciation would be associated with the selective repression of the "unuseful" forms. It is expected that in cancer a reappearance of the norisally repressed forms would occur.

Phosphofructokinase differs, therefore, from other enzymes which $p$ ssess forms expressed in all tissues in the fetal period and have tissue-specific isozymes that appear later. These isozymes (line liver aldolase and muscle creatine kinase) are strong tissue markers, whereas phosphofructokinase isozymes appear to be weak tissue markers.

We have recently proven that, in adult man, three basic forms of phosphofructokinase exist, corresponding to the subunits $M$ (muscle type), L (liver type) and $\mathrm{F}$ (fibroblast type) ( 1,8$)$. Homogenous $M_{4}, L_{4}$, and $F_{4}$ tetramers have been purified $(1,6)$ and specific antisera have been prepared $(1,6,8,11)$. Molecular weight of the $M$ and $F$ subunits has been shown to be about 85,000 and that of the L-subunits about $80,000(1,6)$. In addition, the different phosphofructokinase forms can easily be distinguished according to their antigenicity and their electrophoretic and chromatographic properties $(1,6,8,11)$. In this paper, we study the nature of the phosphofructokinase forms synthesized in the tissues of two 3- and 4-month-old human fetuses.

\section{MATERIALS AND METHODS}

\section{MATERIALS}

Special chemicals and enzymes were obtained from Sigma Chemical Co. (St Louis, MO) Boehringer-Mannheim (West Germany) and Serva (Heildelberg, West Germany). Common chemicals were standard reagent grade. DEAE-cellulose was supplied by Whatman (Springfield, Great Britain). CNBr-activated Sepharose 4B and dextran blue were obtained from Pharmacia (Uppsala, Sweden). Acrylamide, bisacrylamide, and sodium dodecyl sulphate (SDS) came from Eastman Kodack (Rochester, NY). Polyethylenelycol 6000 and Nonidet NP-40 were from Fluka AG (Buchs, Switzerland). Cellulose acetate plates were from Helena (Beaumont, Texas). Agarose ("Indubiose") was produced by l'"Industrie Biologique Française" (Lyon, France). SDS-polyacrylamide gradient slab gels were prepared in the laboratory using an "Uniscil" gradient former (Universal Scientific Limited, London, England), and the electrophoreses in polyacrylamide gels were performed in the electrophoresis apparatus provided by the same firm.

Enzyme activities were measured in a Gilford (model 252) spectrophotometer. Absorption at $280 \mathrm{~nm}$ of the column eluates was measured with a Gilson Holochrom model apparatus.

\section{METHODS}

Fetuses. Two fetuses (3- and 4-month-old) were obtained from uterotomies performed for therapeutical abortions with sterilization.

The fetuses were immediately dissected and the organs were stored frozen at $-80^{\circ} \mathrm{C}$ until use.

Adult Tissues and Control Enzymes. Polymorphonuclear cells from normal controls were isolated as previously reported (11).

Fibroblasts from fetal lung and adult skin were studied in phase II (passages 20 to 40 for fetal lung cells, 6 to 30 for adult skin cells). Subcultivation was achieved by trypsination with $0.12 \%$ trypsin. The cells were harvested after they had reached confluency; they were washed in Hanks' solution and collected by centrifugation. Muscle samples were obtained from surgical biopsies. The samples were stored at $-80^{\circ} \mathrm{C}$ until use. The pure phosphofructokinase preparations used as references were obtained as indicated in Refs. 1 and 6.

Tissue Extraction and Enzyme Assays. The tissues were minced with scissors and then homogenized at $0^{\circ} \mathrm{C}$ in a Potter-Elvehjem homogenizer in a $5 \mathrm{mM}$ Tris/phosphate buffer $(\mathrm{pH} 7.5) / 4 \mathrm{mM}$ $\left(\mathrm{NH}_{4}\right)_{2} \mathrm{SO}_{4} / 1 \mathrm{mM}$ diisopropylfluorophosphate/1 $\mathrm{mM}$ e-aminocaproic acid/0.1 mM EDTA/1 mM ATP/1 mM $\mathrm{MgCl}_{2} / 10 \mathrm{mM}$ dithiothreitol/0.1 mM fructose 6-P/0.1 mM fructose $1,6 \mathrm{P}_{2}$.

In some experiments (whose purpose was to determine whether partial proteolysis of phosphofructokinase could occur during cell extraction and enzyme purification), homogenization of the tissues was performed in the presence of a mixture of several antiproteolytic substances composed, in addition to diisopropylfluorophos-

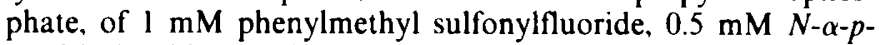
tosyl-lysin chloromethyl ketone, $0.5 \mathrm{mM}$ p-Tosylamido-2-phenyllethyl chloromethyl ketone, $0.05 \mathrm{mM}$ cathepsin $\mathrm{D}$ inhibitor pepstatin, and $2.5 \mu \mathrm{g} / \mathrm{ml}$ cathepsin B inhibitor leupeptin (6). 
The homogenates were centrifuged for $10 \mathrm{mn}$ at $50.000 \times \mathrm{g}$; then enzyme activity was measured at $30^{\circ} \mathrm{C}$ in the supernatants, as reported elsewhere (8); proteins were measured by Lowry's method (10).

Electrophoresis on Cellulose Acetate Plates. The cell extracts were diluted in the electrophoretic buffer to a final activity of 1 unit/ml, then applied to the cellulose acetate plates using the special applicator provided by the manufacturer. Electrophoresis was carried out as previously reported $(6,11)$ in a $5 \mathrm{mM}$ Tris/ maleate buffer ( $\mathrm{pH} 7.2) / 5 \mathrm{mM}\left(\mathrm{NH}_{4}\right)_{2} \mathrm{SO}_{4} / 0.5 \mathrm{mM} \mathrm{ATP} / 0.5 \mathrm{mM}$ $\mathrm{MgCl}_{2} / 0.1 \mathrm{mM}$ dithiothreitol/0.01 $\mathrm{mM}$ fructose $1,6-\mathrm{P}_{2} / 0.1 \mathrm{mM}$ EDTA. The enzyme activity was revealed on the plates by the positive staining described elsewhere $(6,8,11)$.

In some experiments, electrophoresis was performed in the presence of $3 \%(\mathrm{v} / \mathrm{v})$ Nonidet NP-40.

Antisera and Immunological Analysis. Specific anti-M-type, antiL-type, and anti-F-type antisera were used. The preparation and testing of these antisera has been reported in previous papers ( 1 , $6,8,11)$. In particular, it has been shown that they were rigorously monospecific as tested by immunoprecipitation $(1,6)$.

The methods of immunoprecipitation and double immunodiffusion used in this study have been previously described $(1,6,8$, 11).

Purification of Phosphofructokinase. $\left(\mathrm{NH}_{4}\right)_{2} \mathrm{SO}_{4}$ fractionation was performed as described $(1,8)$; enzyme from all the fetal tissues studied was recovered in the 30 to $55 \%\left(\mathrm{NH}_{4}\right)_{2} \mathrm{SO}_{4}$ saturation fraction.

For all the chromatographies, a same buffer (called buffer A) was used; it was a $20 \mathrm{mM}$ Tris/phosphate buffer $(\mathrm{pH} 7.5) / 10 \mathrm{mM}$ $\left(\mathrm{NH}_{4}\right)_{2} \mathrm{SO}_{4} / 10 \mathrm{mM} \mathrm{KF} / 10 \mathrm{mM}$ dithiothreitol/0.1 mM EDTA/ $0.01 \mathrm{mM}$ fructose $1,6 \mathrm{P}_{2} / 1 \mathrm{mM}$ diisopropylfluorophosphate. All the DEAE cellulose, Sephadex G-25, and dextran blue-Sepharose columns were equilibrated with this buffer. The DEAE-cellulose chromatographies were carried out at $18^{\circ} \mathrm{C}$; the other chromatographies were carried out at $4^{\circ} \mathrm{C}$. After desalting on a Sephadex G-25 column, phosphofructokinase was fixed on a DEAE-cellulose column, then eluted by a linear gradient between buffers $A$ and A containing $100 \mathrm{mM}\left(\mathrm{NH}_{4}\right)_{2} \mathrm{SO}_{4}, 100 \mathrm{mM} \mathrm{KH_{2 }} \mathrm{PO}_{4}$, adjusted at $\mathrm{pH} 7$ with solid Tris $(6,11)$.

After $\left(\mathrm{NH}_{4}\right)_{2} \mathrm{SO}_{4}$ precipitation and desalting on a Sephadex G25 column, the extracts were applied to dextran blue Sepharose 4 B columns $(1,8,12)$ equilibrated with buffer $A$. The absorbent was washed with buffer $A$ containing $0.1 \mathrm{mM} \mathrm{MgCl}_{2}$ and different $\mathrm{KCl}$ concentrations according to the nature of the phosphofructokinase forms to be eluted (see Table 3). Elution was provoked by addition of $0.05 \mathrm{mM} \mathrm{ADP}$ and $1 \mathrm{mM}$ fructose $6-\mathrm{P}$ to the washing buffer. The active eluates were lyophilized, then dialysed and dissociated by SDS.

Proteolytic Treatment of Fetal Liver Phosphofructokinase. Onehalf of the fetal liver enzyme preparation obtained after DEAEcellulose chromatography was treated with subtilisin before being purified on Dextran Blue Sepharose. Subtilisin $(0.25 \mu \mathrm{g} / \mathrm{ml})$ was added to the enzyme in buffer $A$. After $30 \mathrm{~min}$ incubation at $37^{\circ} \mathrm{C}$, proteolysis was stopped by addition of $1 \mathrm{mM}$ diisopropylfluorophosphate. This did not result in loss of enzyme activity.

SDS-Polyacrylamide Gradient Slab Gel Electrophoresis. Electrophoresis in SDS-polyacrylamide slab gel was performed according to Laemmli (9), except that the running gel was a 9 to $24 \%(w / v)$ polyacrylamide gradient gel. Migration was continued for $15 \mathrm{hr}$ with a current of $20 \mathrm{~mA} /$ plate $(3 \times 90 \times 100 \mathrm{~mm})$. The proteins were then fixed, and SDS was eliminated by continuous agitation for $8 \mathrm{hr}$ in a $50 \%(\mathrm{v} / \mathrm{v})$ methanol/10\% $(\mathrm{v} / \mathrm{v})$ acetic acid solution which was changed every $2 \mathrm{hr}$. Proteins were stained with Coomassie Blue.

\section{RESULTS}

\section{IMMUNOLOGIC CHARACTERIZATION}

Table 1 shows the results of the immunologic characterization of phosphofructokinase from the various fetal organs.

An apparently paradoxal finding of these results needs to be
Table 1. Immunological analysis of fetal tissue phosphofructokinase

\begin{tabular}{|c|c|c|c|c|c|}
\hline & & \multirow{2}{*}{$\begin{array}{l}\text { Specific } \\
\text { activity } \\
(\mathrm{IU} / \mathrm{mg})\end{array}$} & \multicolumn{3}{|c|}{$\begin{array}{l}\text { \% of residual activity after neutraliza- } \\
\text { tion by excess }\end{array}$} \\
\hline & & & Anti-M & Anti-L & Anti-F \\
\hline \multirow[t]{2}{*}{ Liver } & $1^{2}$ & $0.20-0.40$ & $40-50$ & $<10$ & $67-77$ \\
\hline & 2 & $0.05-0.15$ & $50-60$ & $<10$ & $90-100$ \\
\hline \multirow[t]{2}{*}{ Kidney } & 1 & $0.15-0.25$ & $40-48$ & $10-15$ & $65-75$ \\
\hline & 2 & $0.12-0.19$ & $30-35$ & $10-22$ & $70-80$ \\
\hline \multirow[t]{2}{*}{ Brain } & 1 & $0.18-0.23$ & $20-28$ & $25-35$ & $59-69$ \\
\hline & 2 & $0.13-0.19$ & $20-25$ & $30-50$ & $60-80$ \\
\hline \multirow[t]{2}{*}{ Lung } & 1 & $0.15-0.25$ & $35-43$ & $8-15$ & $68-75$ \\
\hline & 2 & $0.10-0.18$ & $30-35$ & $5-15$ & $75-85$ \\
\hline \multirow[t]{2}{*}{ Heart } & 1 & $0.50-1.0$ & $70-90$ & $75-100$ & $8-12$ \\
\hline & 2 & $0.50-1.0$ & $50-60$ & $60-75$ & $25-35$ \\
\hline \multirow[t]{2}{*}{ Muscle } & 1 & $0.50-0.70$ & $15-25$ & $75-85$ & $>90$ \\
\hline & 2 & $0.33-0.60$ & $5-15$ & $85-95$ & $80-85$ \\
\hline Yolk sack & 2 & $0.10-0.15$ & $>90$ & $20-30$ & $<10$ \\
\hline \multirow[t]{2}{*}{ Thymus } & 1 & $0.10-0.20$ & $75-85$ & $10-15$ & $35-45$ \\
\hline & 2 & $0.10-0.20$ & $50-60$ & $10-20$ & $35-45$ \\
\hline \multirow[t]{2}{*}{ Adrenals } & 1 & $0.10-0.20$ & $10-20$ & $35-40$ & $>90$ \\
\hline & 2 & $0.10-0.20$ & $10-20$ & $50-60$ & $80-90$ \\
\hline \multirow[t]{2}{*}{ Spleen } & 1 & $0.05-0.10$ & $40-60$ & $10-20$ & $55-65$ \\
\hline & 2 & $0.05-0.99$ & $50-60$ & $5-15$ & $58-65$ \\
\hline Stomach & 1 & 0.105 & $>90$ & $25-30$ & $9-18$ \\
\hline Pancreas & 1 & 0.145 & $50-75$ & $13-19$ & 90 \\
\hline Skin & 1 & 0.086 & 75 & $15-25$ & 80 \\
\hline \multirow[t]{2}{*}{ Placenta } & 1 & 0.14 & $75-80$ & $<10$ & $55-62$ \\
\hline & 2 & $0.06-0.11$ & $60-65$ & $15-35$ & $50-75$ \\
\hline
\end{tabular}

All the results reported in this table were obtained from at least three independent measures whose extreme values are given. When these values were not significantly different, only one result is given.

2 3-month-old fetus; 2, 4-month-old fetus.

briefly commented on. The sum of the percentages of the activity neutralized by each antiserum is more than $100 \%$. It is because the technique used is an immunoprecipitation $(1,8,11)$; thus, a hybrid molecule can be totally precipitated by the different antisera recognizing one or several of its subunits.

The anti-L-type antiserum was the most active in neutralizing enzyme from liver, kidney, lung, thymus, spleen, pancreas, skin, and placenta. This signifies that L-type phosphofructokinase is the predominant form in these tissues. M-type enzyme seems to be predominant in muscle and coexists with some L-type phosphofructokinase in brain and adrenals. F-type enzyme is the major form in heart and coexists with L-type subunits in yolk sack and stomach. As a matter of fact, two or three types of subunits seem to exist in all fetal tissues. No important difference between the 3and 4-month-old fetus was detected.

\section{ELECTROPHORETIC CHARACTERIZATION}

Figure 1 shows that phosphofructokinase from fetal liver exhibited a fast mobility and migrated practically in the same position as $\mathrm{L}_{4}$ phosphofructokinase from polymorphonuclear cells (11). Fast enzymatic forms were also predominant in fresh kidney extracts. Adrenal enzyme exhibited an intermediate mobility between L-type and muscle phosphofructokinase. Heart and yolk sack enzymes were predominantly composed of slow-moving bands migrating in the same position as the $\mathrm{F}_{4}$ band of fibroblast phosphofructokinase (11), which is coherent with the immunologic evidence that they were mainly composed of F-type subunits. As for fetal muscle phosphofructokinase, it exhibited a very slow mobility and migrated as a broad, tailing band.

Because of the complexity of the electrophoretic pattern expected for a random combination of three different subunits into tetrameric forms (yielding up to 15 different species), it is practically impossible with this method to recognize the isozymic nature of phosphofructokinase with certainty. 


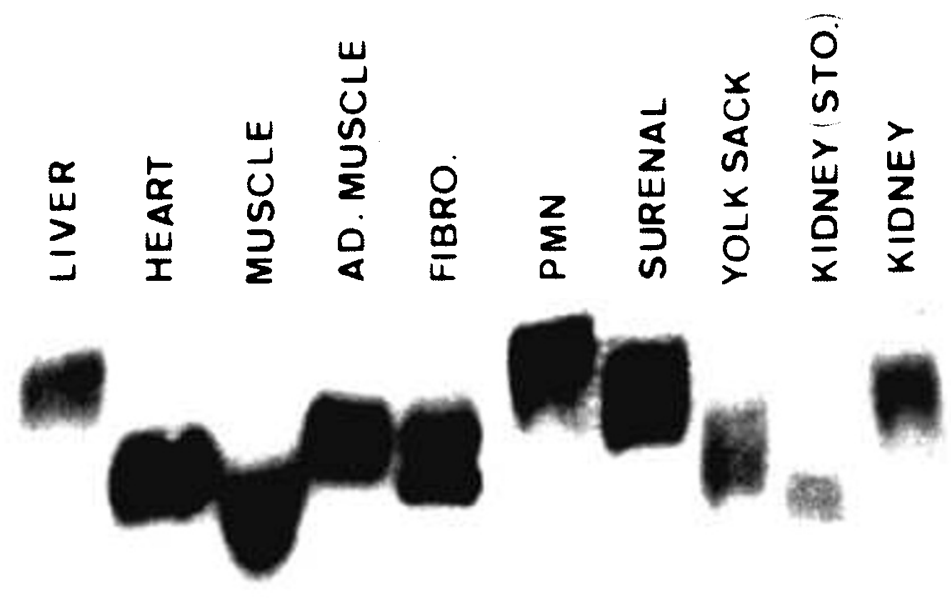

\section{$\begin{array}{llllllllll}1 & 2 & 3 & 4 & 5 & 6 & 7 & 8 & 9 & 10\end{array}$}

Fig. 1. Cellulose acetate electrophoresis of phosphofructokinase from fetal tissues. I, fetal liver; 2 , fetal heart; 3 , fetal muscle; 4 , adult muscle, 5 , fibroblasts from fetal lung, 38th passage; 6 , adult polyporphonuclear cells; 7 , fetal adrenals; 8 , yolk sack; 9 , fetal kidney, sample stored frozen for 3 months; 10, fetal kidney, fresh extract. All these extracts were freshly extracted, except sample 2. For further details, see "Methods."

In addition, we have previously shown that on aging L-type enzyme and L-type-containing hybrids could be transformed into slow-moving forms which could be interpreted as aggregates $(8$, 11). This latter finding is well illustrated in Figure 1 for kidney enzyme which exhibited a fast mobility in a freshly extracted sample and a slow mobility when a stored sample was used. This secondary conversion of phosphofructokinase into slow-moving aggregates can be partially reversed by using the non-ionic detergent Nonidet NP-40 added to the electrophoretic buffer (Fig. 2). In this latter condition, the fast mobility of L-type phosphofructokinase was observed even when stored, several times frozen, and thawed samples were used. In the presence of Nonidet NP-40, mobility of fetal muscle enzyme was increased, but remained slightly slower than that of adult muscle (Fig. 2).

\section{FURTHER COMPARISON OF ADULT AND FETAL MUSCLE PHOSPHOFRUCTOKINASE}

The slow mobility of fetal muscle enzyme could be partly explained by aggregation, which could account for the influence of the detergent Nonidet NP-40 on its electrophoretic migration (Fig. 2).

A difference of charge, however, seemed also to exist between fetal and adult muscle-type phosphofructokinase; it was confirmed by chromatography on DEAE-cellulose (Fig. 3). The major peak of the fetal muscle enzyme was eluted at lower ionic concentration than for the adult tissues. In addition, some minor forms of fetal muscle phosphofructokinase were eluted at higher ionic concentration. Table 2 shows that immunologically they seemed to correspond to $\mathrm{M}-\mathrm{L}$ hybrids.

When compared by double immunodiffusion and immunoneutralization tests, fetal muscle phosphofructokinase (peak 1) and adult enzyme were identical (not shown).

SDS-POLYACRYLAMIDE GEL ANALYSIS OF THE PHOSPHOFRUCTOKINASE SUBUNITS PURIFIED FROM FETAL TISSUES

Figure 4 shows that using the proposed method of affinity chromatography on dextran blue Sepharose 4B (Table 3; Refs. 1 and 6), it was possible to purify phosphofructokinase from the various fetal organs to a sufficient degree to allow its direct analysis by SDS-polyacrylamide gel electrophoresis (Figs. 4 and
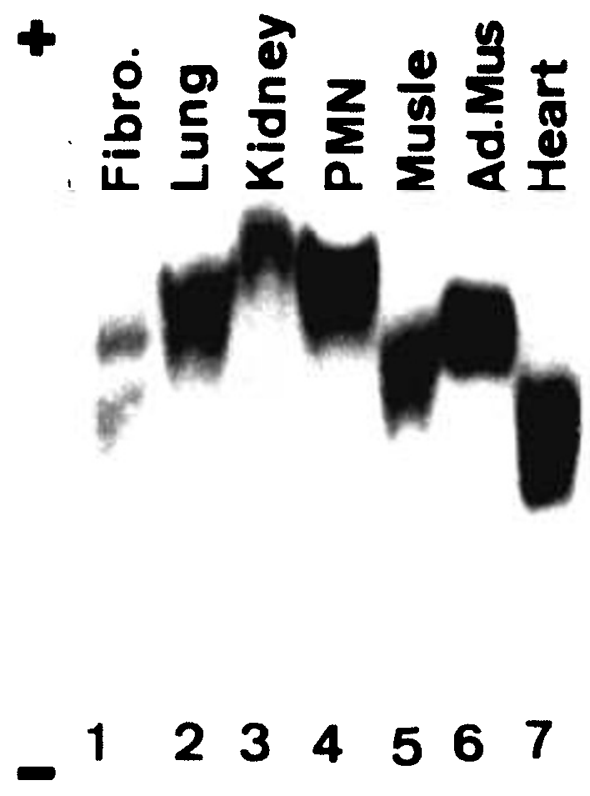

Fig. 2. Cellulose acetate electrophoresis of phosphofructokinase in the presence of $3 \%(\mathrm{v} / \mathrm{v})$ Nonidet NP-40. 1, fibroblasts (idem. Fig. 1); 2, fetal lung; 3, fetal kidney; 4, adult polymorphonuclear cells; 5 , fetal muscle; 6 , adult muscle; 7 , fetal heart.

5). By these methods, phosphofructokinase was purified 200- to 600 -fold and was more than $80 \%$ pure.

SDS-polyacrylamide gel electrophoresis does not enable F- and $\mathrm{M}$-type subunits to be distinguished, both having the same molecular weight (i.e., about 85,000 ). By contrast, the L-type subunits 
of red cell phosphofructokinase have a molecular weight of about 81,000 . Figure 4 shows, in addition, that L-type subunits purified from granulocytes have a molecular weight slightly lower than Ltype subunits from red cell enzymes.

The fetal enzymes had subunits corresponding to two different molecular weights: 85,000 (like M- or F-type subunits) or 81,000 (like L-type subunits of red cell phosphofructokinase). Fetal heart phosphofructokinase was composed only of heavy subunits, whereas some minor light subunits were observed for fetal muscle.

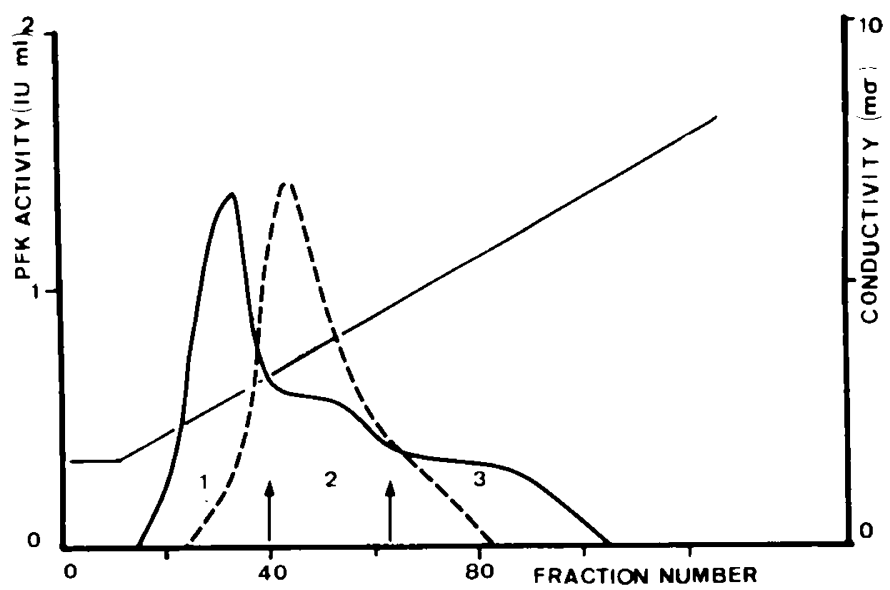

Fig. 3. Elution profile of phosphofructokinase from DEAE-cellulose columns. Full thick line, fetal muscle, enzyme activity; - - - , adult muscle, enzyme activity; - - conductivity.

Table 2. Immunological characterization of the chromatographic peaks of fetal muscle phosphofructokinase

\begin{tabular}{lrcr} 
& \multicolumn{3}{c}{$\begin{array}{c}\text { \% of residual activity after neutralization } \\
\text { by excess }\end{array}$} \\
\cline { 2 - 4 } & anti-M & anti-L & anti-F \\
\hline Fetal muscle & & & \\
Crude extract & 18 & 78 & $>90$ \\
Peak 1 & $<10$ & 100 & 87 \\
Peak 2 & 12 & 85 & $>90$ \\
Peak 3 & 27 & 58 & $>90$ \\
& & & $>90$ \\
Adult muscle & $<10$ & $>90$ & \\
\hline
\end{tabular}

Both types of subunits were present in identical amounts in fetal brain. As for fetal liver, it contained mainly light subunits. These results fully confirm the immunological data; those tissues which reacted mainly with anti-L-type antiserum (e.g., fetal liver) are predominantly composed of light, L-type subunits; fetal brain enzyme, inhibited by both anti-L-type and anti-M-type antisera, is indeed composed of both light, L-type and heavy, M-type subunits. Fetal muscle enzyme reacted predominantly with antiM-type and slightly with anti-L-type antisera; it is composed of predominantly heavy subunits and minor light subunits. Finally, fetal heart phosphofructokinase was significantly neutralized only by anti-F-type antiserum; it is composed of heavy subunits which here most likely correspond to F-type subunits.

In Figure 5, we show that a mild proteolysis of fetal liver enzyme by subtilisin converted the L-type subunits into slightly lighter forms, with similar molecular weight to the L-type subunits of granulocytes enzyme, or with F-L hybrids purified from platelets $(1,6)$. The same proteolytic treatment modified the chromatographic behavior of fetal liver enzyme; it increased the strength of its fixation to the dextran blue Sepharose 4B columns, that is to say, the ionic concentration able to provoke its elution (Table 3 ). Thus the chromatographic behavior of subtilisin-treated fetal liver phosphof ructokinase closely resembled that of granulocyte enzyme (Fig. 3; Refs. 1 to 6).

\section{DISCUSSION}

From the immunologic characterization of phosphofructokinase in various fetal tissues, we suggest the isozymic composition summarized in Table 4. These isozymic formulae were coherent with the electrophoretic pattern and were confirmed by purification of the enzyme and SDS-polyacrylamide gel electrophoresis of the dissociated subunits. The first result to be pointed out is that, at least after 3 months of intra-uterine life, no form of phosphofructokinase can be considered as "specifically fetal." In fact, most of the fetal tissues expressed two or three types of enzymes subunits, and it is rather this indiscriminate expression of the different types of phosphofructokinase which is characteristic of fetal tissues.

As compared with adult tissues, heart and brain showed some major differences. Adult heart contains mainly $\mathbf{M}$-type subunits $(1,8)$; fetal heart contains mainly F-type subunits.

Adult brain enzyme is also composed of M-type subunits as major form, and F-type as minor form $(1,8)$. In the fetal brain, $M-$ and L-type subunits are present in approximately the same amount.

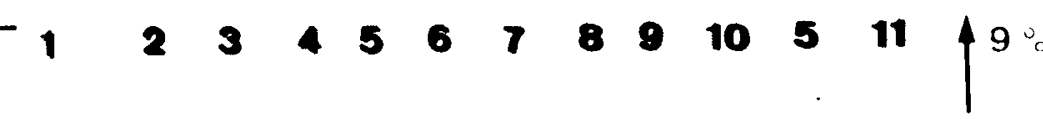

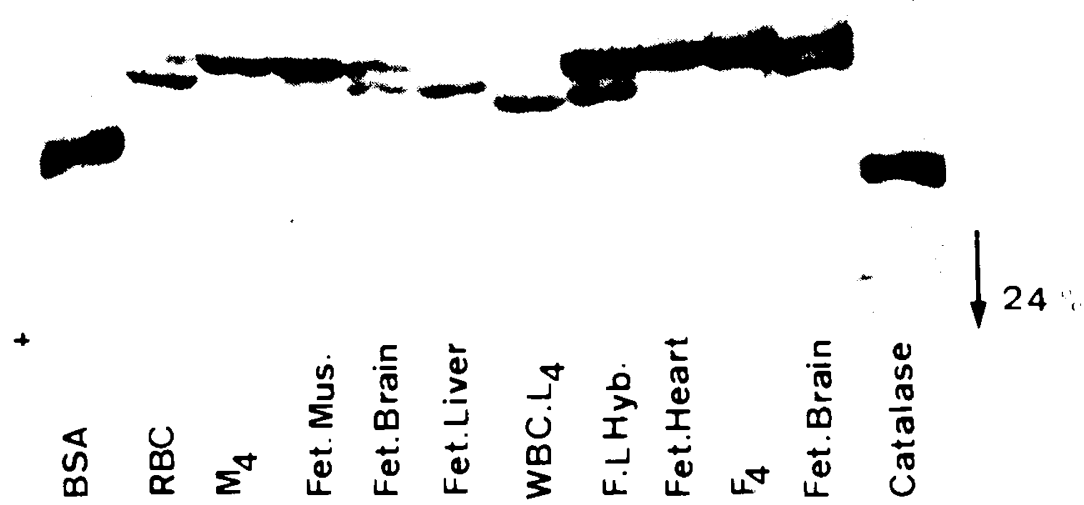

Fig. 4. SDS-polyacrylamide gradient gel electrophoresis of purified phosphofructokinase preparations. Staining with Coomassie blue. About 3 to 5 $\mu \mathrm{g}$ proteins per sample. 1 , bovine serum albumin; 2 , adult red cell enzyme; 3 , adult muscle enzyme; 4 , fetal muscle enzyme; 5 , fetal brain enzyme; 6 , fetal liver enzyme; $7, L_{4}$ enzyme from white blood cells; 8, F-L hybrids from platelets; 9 , fetal heart enzyme; $10, F_{4}$ enzyme from platelets; 11 , catalase. 


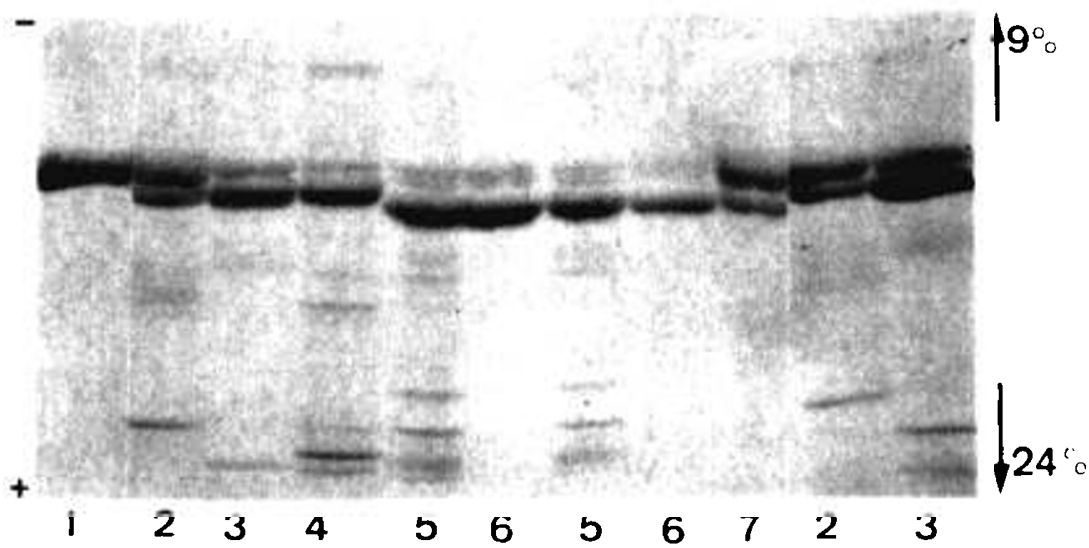

Fig. 5. SDS-polyacrylamide gradient gel electrophoresis. Influence of subtilisin on fetal L-type subunits. 1, $\mathbf{M}_{4}$ enzyme from adult muscle; 2 , fetal brain enzyme; 3 , phosphofructokinase from adult red cells; 4, fetal liver enzyme; 5 , fetal liver enzyme after subtilisin treatment; 6 , enzyme from adult granulocytes (mixture of $L_{4}$ and minor F-L hybrids); 7, F-L hybrids from platelets.

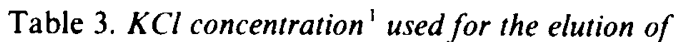
phosphofructokinase from the dextran blue Sepharose $4 B$ columns

\begin{tabular}{lr} 
Fetal tissues & \\
$\quad$ Liver (fresh tissue) & $80 \mathrm{mM}$ \\
Liver (After treatment with subtilisin) & $150 \mathrm{mM}$ \\
Brain & $80 \mathrm{mM}$ \\
Heart & $150 \mathrm{mM}$ \\
Muscle & $60 \mathrm{mM}$ \\
& \\
Adult tissues & \\
Red cells (L-M hybrids) & $80 \mathrm{mM}$ \\
Granulocytes (L) & $200 \mathrm{mM}$ \\
Muscle & $30 \mathrm{mM}$ \\
F $_{4}$ & $200 \mathrm{mM}$ \\
\hline
\end{tabular}

' This concentration corresponds to $\mathrm{KCl}$ added to buffer $\mathrm{A}$ for washing the column before elution. Elution is provoked by adding ADP and fructose 6-P to this buffer.

At 3 months of fetal life, liver phosphofructokinase is already composed mainly of L-type enzyme, associated with some M-type subunits (whereas F, but not M-type subunits are present in adult liver).

Fetal thymus contains the same type of phosphofructokinase as cultured lymphoid lines (11).

Immunologically, the main difference between fetal and adult muscle is the presence, in the former, of some L-type enzyme; this presence is confirmed by chromatographic analysis and total purification followed by SDS-polyacrylamide gel electrophoresis of the fetal enzyme.

In addition, however, M-type enzyme from fetal muscle seems to be different from the adult enzyme: it is electrophoretically more cathodic and is eluted first during chromatography on DEAE-cellulose. By contrast, both types exhibit similar antigenicity and molecular weight. We cannot, so far, choose between two alternative possibilities: either fetal and adult M-type enzymes are the products of two closely related genes, one expressed during the fetal life and the other after birth, or they correspond to two molecular forms of a same gene product. In favor of the latter possibility is the evidence presented by Uyeda et al. (14) that two chromatographically distinguishable forms of rabbit muscle phosphofructokinase correspond to different level of phosphorylation.

Thus, it could be that in fetal muscle M-type phosphofructokinase exists in a dephosphorylated form whereas phosphorylation could occur during differentiation of the fetal muscle toward the adult form.

Another question concerns the relationship between the fetal Ltype subunits (which seem to be similar to the adult L-type subunits of red cells and liver) and the L-type subunits purified from leukocytes or platelets; although all these forms exhibit
Table 4. Suggested subunit composition of fetal phosphofructokinase as compared with adult tissues (8)

\begin{tabular}{|c|c|c|c|}
\hline & $\mathbf{M}$ & L & $\mathrm{F}$ \\
\hline \multicolumn{4}{|l|}{ Liver } \\
\hline Fetus & + & +++ & \\
\hline Adult & & +++ & + \\
\hline \multicolumn{4}{|l|}{ Kidney } \\
\hline Fetus & ++ & +++ & + \\
\hline Adult & & +++ & ++ \\
\hline \multicolumn{4}{|l|}{ Brain } \\
\hline Fetus & +++ & +++ & + \\
\hline Adult & +++ & + & ++ \\
\hline \multicolumn{4}{|l|}{ Heart } \\
\hline Fetus & & & $++t$ \\
\hline Adult & +++ & & \\
\hline \multicolumn{4}{|l|}{ Muscle } \\
\hline Fetus & +++ & + & \\
\hline Adult & +++ & & \\
\hline Yolk sack & & ++ & +++ \\
\hline Fetal thymus & + & +++ & ++ \\
\hline Cultured lymphoid lines & + & +++ & ++ \\
\hline Cultured fibroblasts & & + & +++ \\
\hline Placenta & + & +++ & + \\
\hline
\end{tabular}

similar antigenicity and have similar elution profiles on DEAEcellulose chromatography, the latter have a slightly lower molecular weight and a stronger fixation to dextran blue Sepharose 4B than the former.

It is always difficult to affirm that the molecular weight of a purified enzyme corresponds, in fact, to that of the native, recently synthesized enzyme; proteolysis phenomena may occur in vivo with postsynthetic maturation or aging $(6,7)$ and in vitro. It is the reason why we verified molecular weight of the phosphofructokinase subunits purified from cell extracts treated with various antiproteolytic substances, especially with anticathepsins and found no difference from the results obtained when purification was carried out in the usual conditions. Although this approach does not definitely eliminate the possibility of such a partial proteolysis in the course of purification, it does at least reduce the likelihood of such an eventuality.

Because a mild proteolytic attack of fetal liver phosphofructokinase by subtilisin transforms its L-type subunits into subunits with similar molecular weight to adult granulocyte enzyme, without inactivating enzyme activity, we may suppose that a postsyn- 
thetic proteolysis of the L-type subunits could account for their characteristics in adult leukocytes. This assumption is further supported by the enhancement of the binding strength of the fetal liver enzyme to dextran blue Sepharose $4 \mathrm{~B}$ after subtilisin treatment. If this postulated mechanism was confirmed, it would be an additional example of the postsynthetic, proteolytic processing of glycolytic enzymes that we have especially documented for pyruvate kinase (7) and glucose 6-phosphate dehydrogenase (5).

Very few studies dealing with phosphofructokinase from mammalian fetal organs have so far been published, and this paper reports the first study in man. De Faria et al. (2) reported, in rabbit and guinea pig, a transition in synthesis from isozyme $\mathrm{C}$ (corresponding to our F-type enzyme) to isozyme A (muscle type) which takes place in heart and muscle. These findings fully agree with our own data for heart but not for muscle. Because the only method used by De Faria et al. (2) is cellulose acetate electrophoresis, we cannot, however, exactly compare their results with ours; we have pointed out, in this paper, that electrophoresis alone did not permit determination of the complete isozymic nature of phosphofructokinase.

Dunaway et al. (4) reported, in rat tissues, results very similar to ours for fetal muscle, brain, kidney, and liver, namely the presence of L-type phosphofructokinase. By contrast, these authors described fetal heart enzyme as composed of $\mathrm{M}$ - and L-type enzyme whereas we have proven that in man F-type phosphofructokinase was predominant.

\section{CONCLUSION}

In conclusion, we describe in this paper the isozymic composition of phosphofructokinase in human fetal organs. No isozyme can be considered as specifically "fetal," the fetal tissues being rather characterized by the indiscriminate synthesis of two or three of the basic types of phosphofructokinase.

In particular, L-type phosphofructokinase, which is known as a highly regulatory enzyme in adult hepatocytes $(3)$, is present in practically all of the fetal tissues except heart. This is in striking contrast with other systems (e.g., aldolase and pyruvate kinase; Ref. 13) in which the adult, differentiated enzymes are not or only slightly synthesized in the fetus. M-type phosphofructokinase from fetal muscle differs slightly from the adult enzyme; the nature (genetic or posttranslational) of this difference remains undetermined. The fetal L-type subunits seem to be similar to the L-type subunits of red cell enzyme, but have a slightly higher molecular weight than do the subunits of adult granulocyte enzyme. After partial treatment with subtilisin, molecular weight and chromatographic properties of fetal liver phosphofructokinase become very similar to those of the granulocyte enzyme. Thus, we suggested that L-type phosphofructokinase could undergo a postsynthetic, proteolytic processing in some tissues.

\section{REFERENCES AND NOTES}

1. Cottereau, D., Levin, M. J., and Kahn. A.: Purification and partial characterization of different forms of phosphofructokinase in man. Biochim. Biophys. Acta, 568: 183 (1979).

2. de Faria, J. B.. El Dorry, H. A., and Bacila. M.: Multiple forms of phosphofructokinase in developing rabbit and guinea pig tissues. Dev. Biol., 65: 547 (1978).

3. Dunaway. G. A., Leung, G. L. Y., Cooper. M. D., Thrasher, J. R., and Wagle, S. R.: Distribution of hepatic phosphofructokinase isozymes in parenchymal and sinusoidal cells. Biochem. Biophys. Res. Commun., 80: 71 (1978).

4. Dunaway, G. A., Leung. G. L. Y., and Thrasher, J. R.: Phosphofructokinase isozyme patterns in fetal, neonatal and adult rat tissues (1798). Fed. Proc.. 37 (1978).

5. Kahn, A., Bertrand, O., Cottereau, D., Boivin, P., and Dreyfus, J. C.: Evidence for structural differences between human glucose-6-phosphate dehydrogenase purified from leukocytes and erythrocytes. Biochem. Biophys. Res. Commun., 77: 65 (1977).

6. Kahn, A., Cottereau, D., and Meienhofer. M. C.: $F_{4}$ phosphofructokinase: purification from human platelets and comparison with the other phosphofructokinase forms. Biochim. Biophys. Acta, 6/1: 114 (1980).

7. Kahn. A., Marie, J., Garreau. H., and Sprengers, E. D.: The genetic system of the L-type pyruvate kinase forms in man. Subunit structure, interrelation and kinetic characteristics of the pyruvate kinase enzymes from erythrocytes and liver. Biochim. Biophys. Acta, 523: 59 (1978).

8. Kahn. A., Meienhofer, M. C.. Cottereau, D., Lagrange, J. L., and Dreyfus, J. C.: Phosphofructokinase (PFK) isozymes in man. I. Studies of adult human tissues. Hum. Genet., 48: 93 (1979).

9. Laemmli. U. K.: Cleavage of structural proteins during the assembly of the head of bacteriophage $T_{4}$. Nature (Lond.), 227: 680 (1970).

10. Lowry, O. H., Rosebrough, N. J., Farr, A. L., and Randall, R. J.: Protein measurement with the folin phenol reagent. J. Biol. Chem., 193: 265 (1951).

11. Meienhofer, M. C., Lagrange, J. L., Cottreau. D., Lenoir, G., Dreyfus. J. C., and Kahn. A.: Phosphofructokinase in human blood cells. Blood, 54 : 389 (1979).

12. Ryan, L. D., and Vestling, C. S.: Rapid purification of lactate dehydrogenase from rat liver and hepatoma: a new approach. Arch. Biochem. Biophys., 160 . 512 (1974).

13. Schapira. F.: Isozymes and Cancer. Adv. Cancer Res., 18: 77 (1973).

14. Uyeda. K., Miyatake. A.. Luby, L. J.. and Richards. E. G.: Isolation and characterization of muscle phosphofructokinase with varying degrees of phosphorylation. J. Biol. Chem.. 253: 8319 (1978).

15. Requests for reprints should be addressed to: A. Kahn, M.D., Ph.D., Chu Cochin. 75674 Paris Cedex 14 (France).

16. This research was supported by Grant ATP 56-78-88 from Inserm.

17. Received for publication June 28,1979

18. Accepted for publication January 7, 1980 